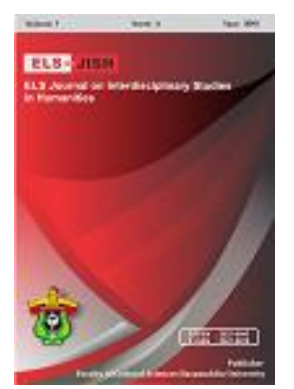

ELS-JISH

ELS Journal on Interdisciplinary Studies on Humanities

Volume 1 Issue 3, 2018

ISSN (print) : 2621-0843

ISSN (online) : 2621-0835

Homepage : http://journal.unhas.ac.id/index.php/jish

\title{
The Comparison of Mandarin Aspects and Indonesian Aspects
}

\author{
Elvira Septevany ${ }^{1}$ \\ vhira libra@yahoo.com
}

\begin{abstract}
For the foreigner students, Time aspects (usually can be referred as aspects) in Mandarin is a difficult grammar to be grasped. Indonesian student is no exception. There is only a little bit of similarities exist between Mandarin and Indonesian time aspects. For the example from the semantics point of view: Mandarin "le" and Indonesian "sudah" both of them can modify verbs to indicate an action that have been finished. Mandarin "zhe" and Indonesian "sedang" both of them also modify verbs indicating action that still happen. Mandarin "guo" and Indonesian "pernah" both of them also can modify verbs indicating action that had been happened, etc. Except these similarities, Mandarin and Indonesian time aspects have a lot of differences. For the example, in Mandarin time aspects are usually placed after the verbs, while in Indonesian time aspects placed before the verbs. Mandarin time aspects can only modify verb, while Indonesian can modify verb and adjective. For example, in Mandarin the action is already happened, it can't use the adverb of frequency "chang-chang". Eg "ta chang-chang shang xue chi dao le". We can't write it like this. But In Indonesian "sudah" can use adverb of frequency "sering" in sentences, eg : "dia sudah sering terlambat". This sentences in Indonesian is correct. So, this paper will be analyzed the grammar of Mandarin aspect "le, zhe, guo" with Indonesian aspect "sudah, sedang, pernah", compared both of them, and find the differences between both of them.
\end{abstract}

Keywords: Mandarin aspect; Indonesian aspect; Comparative analysis.

How to cite: : Septevany, E. (2018). The Comparison of Mandarin Aspects and Indonesian Aspects. ELS Journal on Interdisciplinary Studies in Humanities, 1 (3), 366-374

\section{Introduction}

Every ethnic has their own language. Although every ethnic has their own differences but they also have similarities. Mandarin and Indonesian came from the different language family. Mandarin came from Sino-Tibetan language family, and Indonesian came from Austronesia language family. That difference aside, they also came from different type of language. Mandarin is included as isolative language, this type of language depends on their word order, add structure word, and word compound to create a functional word. While Indonesian is included in Agglutinative language, which have a lot of changes in their basic word, they also have a lot of suffixes. This is the reason why, these languages have many differences, take both of the language's aspect as example.

The biggest differences in both language aspect is the word class of those aspect itself. Mandarin aspect is categorized as auxiliary word, while Indonesian categorized as

\footnotetext{
${ }^{1}$ Nanchang University, China 
adverb, those differences can be seen in one of the aspect, takes "le" and "sudah" as an example. Aspect "le" in Mandarin can't be paired with adverb of frequency because in Mandarin "le" indicating something that recently happening, already happening, or happening in the past. While adverb of frequency in Mandarin indicating an event or action that usually happened, or always happened. So, we can't decide whether these adverbs of frequency happened in the past or present. These uncertainties are the reason why "le" can't be paired with adverb of frequency in Mandarin. In Indonesian "sudah" can be paired with adverb of frequency. Because in Indonesian adverb of frequency more emphasizing to "the amount of frequency" of an event. Also, it won't disturb the placement of "sudah". Those differences will be explained in this paper. From these differences started, the author will search the differences between the aspect of two languages. But, before the author explain the differences, the author will explain their similarities.

\section{Method}

This research is descriptive qualitative, the author used contrastive analysis to analyze the data. According to Kridalaksana (2008:145) contrastive linguistic is a synchronized method that used to analyzing languages, which the purpose of this method is to show the differences or similarities between languages or dialects and to search the principle that can be used easily, such as language teaching and translation. With using this theory, the author will analyze the differences and similarities between aspects in Mandarin and Indonesian.

\section{The Analysis}

\subsection{The Simmilarities In Mandarin Aspect And Indonesian Aspect}

\subsubsection{The similarities of Mandarin "zhe" and Indonesian aspect "sedang":}

Jian and Zhen (1999) stated that "zhe" indicates an action or event that still continues. Through the analysis of various sentences, he concludes that "zhe" can be using to explain an action that still happen or still in the undergoing process. Using the data that provided by Mr. Lu, the author using it as references to compare between Indonesian and Mandarin. And the result is there is only one similarities between Indonesia aspect and Mandarin aspect that is $(\mathrm{V}+$ "sedang" $+\mathrm{O})$ structure. $(\mathrm{V}+$ "sedang" $+\mathrm{O})$ $=\mathrm{V}+$ "zhe" $+(\mathrm{O})$ in Mandarin "zhe" usually placed after the verb, "sedang" $+\mathrm{V}+\mathrm{O}$ in Indonesia "sedang" is placed before the verb. Eg:

Mandarin : (33) ta zai xi zhe yifu ne.

Indonesian : Dia/ta sedang/zhe, zai, zhengzai, mencuci/xi baju/yifu. He is washing clothes.

Using the special characterization of "zhe" in Mandarin language, I compare it with Indonesian "sedang". Through this comparison I find 4 similarities from the way we use "zhe" and "sedang", that is:

1. From the semantics point of view; both of the indicating the same meaning that is a job/action/event that is still happening and continuing.

2. Both of the aspect can be paired with transitive verbs (jiwu dongci). Eg :

Mandarin : wo mama zheng zou zhe ne.

Indonesian : : Ibu saya sedang berjalan. My mother is walking. 
3. Both of the aspect also can be paired with intransitive verbs (bu jiwu dongci). Eg:

Mandarin : : wo zhengzai kan zhe shu ne.

Indonesian : saya sedang membaca buku. I am reading book

4. Both of the aspect can be used together with adverb of time. Eg:

Mandarin : Zuotian shangke de shihou, ta zhuyi tingzhe laoshi de hua.

Indonesian : Kemarin sewaktu kelas sedang berlangsung, dia memperhatikan dengan seksama perkataan guru. Yesterday when class is starting, he totally concentrates on teacher's lesson.

\subsubsection{The similarities of Mandarin "le" and Indonesian aspect "sudah" :}

Mandarin aspect "le" grammatically can also paired with verb, indicating "finish" and "in progress" status. Shi Yu Zhi (1992) emphasize, "shixian guocheng" ("realization process") is a condition where we can or cannot put "le". If we can put "le" as " $x$ " indicates time in the past, while "a" indicate the "realization" of the action, $x$ and a represent "realization process", the diagram follow as below :

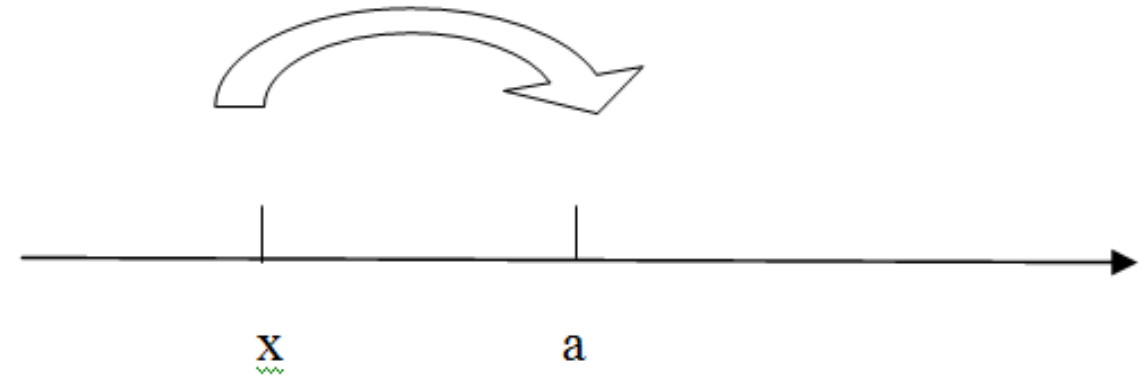

Therefore, "le" is a process from nothing to exist. "le" also must be paired with words that have/posses "realization process" property, but Qin Li Xin in 《“着”“了”“过”时体意义的对立及其句法条件》states that “le” can be divided in two categories: "le" after that placed after the verbs ( $\mathrm{V}$ "le") and "le" that placed in the end of the sentences. He points out that after verbs "le" mostly contains the meaning "recently finished", in different kind of sentence condition they also have different forms, and each indicates different meaning. Some of the meaning included: finished, the status or the condition is still in process. Below, there is 4 similarities between Mandarin aspect "le" and Indonesian aspect "sudah":

1. Finished state

Mandarin : Ta pao le liangge xiaoshi. She already ran for two hours.

Indonesian : Dia sudah berlari selama dua jam

2. Still in process

Mandarin : Hei ban shang xie le yixie zi. At the blackboard already written several words. 
Indonesian : Di papan tulis telah tertulis beberapa huruf. can be paired with adjectives. Eg :

Mandarin : Shu shang de mangguo shu le. The mango that grows on the tree already ripe.

Yinni Yu : Mangga yang di atas pohon sudah masak.

3. "Ie" and "auxiliary verbs (hui, neng) " can be paired.

Mandarin : Ta hui kai che le. She already able to drive a car.

Indonesian : Dia sudah bisa menyetir mobil.

\subsubsection{The similarities of Mandarin "guo" and Indonesian aspect "pernah" :}

Aspect "guo" in Mandarin and Indonesian aspect "pernah" only have two similarities that is: Mandarin aspect "guo" and Indonesian aspect "pernah" have the same meaning indicate "something that already happen in long time". Eg:

Mandarin : Ta chi guo pisha. He ever eat pizza.

Indonesian : Dia pernah makan pizza.

Mandarin aspect "guo" and Indonesian aspect "pernah" both of them can indicate "feilian dong jiegou de dongzuo de" ("recently finished"). At this time both of the aspect must use "le" and "sudah" to states that the action is already finished. Eg:

Mandarin : Wo kan guo le, ni kan ba. I already read this book, now you read it.

(there is the possibilities that I already read this book, and I think it's good, the I recommend it to you to read it or I already read this book and no need to read it again, so you just can take it.)

Indonesian : Saya sudah pernah lihat, kamu lihat saja.

\subsection{The Differences In Mandarin Aspect And Indonesian Aspect And Their Reason}

The most basic reason why there is so many differences between Mandarin aspect and Indonesian aspect, is because their language origin is different each other. Mandarin or Mandarin language can be categorized in isolative language while Indonesian can be categorized as agglutinative language.

The author will be explain about the differences between aspect in Mandarin and aspect in Indonesian.

\subsubsection{The differences between aspect "zhe" and "sedang"}

a. The position is different: Aspect "zhe" is placed after the verb, while aspect "sedang" is placed before the verb.

b. Aspect "zhe" in Mandarin can be used in imperative sentences, it usually placed after the verb, while aspect "sedang" in Indonesian can't be used in imperative sentences because "sedang" means an action or event that still happening in the present time. Eg:

Mandarin :

$(\sqrt{ })$ ni xian xie zhe, wo tiqian chu qu kan kan. 
Indonesian :

(X) Anda istirahat dulu, saya akan keluar terlebih dahulu untuk melihat-lihat. You can take a rest, I will be go outside to have a look.

c. The usage of reduplicated verb which consist of two syllables alongside with aspect "zhe" in Mandarin language. If the verb consist of two syllables then aspect "zhe" can't paired with those syllable because aspect "zhe" can't be inserted between those syllables. If aspect "zhe" is paired with reduplicated verb, then "zhe" must be inserted in the middle of those reduplicated verb that consist of mono syllables. While aspect "sedang" in Indonesian can be paired with reduplicated mono syllables or reduplicated verbs that consist two syllables, because aspect "sedang" can be placed before the reduplicated verbs. Eg :

Mandarin :

$(\sqrt{ })$ ta tingzhe tingzhe jiu shuijiao le. He listens to the music and then fall asleep.

(X) ta zhengzai youzheyong youzheyong zai hu de houmian. He is swimming in the lake behind the house.

Indonesian :

$(\sqrt{ })$ Dia sedang tidur-tidur di bawah pohon. He is take a rest below the tree shades.

$(\sqrt{ })$ Dia sedang mandi-mandi di danau belakang rumah. He is taking a bath in the lake behind the house.

d. The usage of aspect "sedang" with. In Indonesian, aspect "sedang" can became the part of conjunction such as "sedang...sambil...", "tengah...sambil...", "lagi...sambil...". But In Mandarin, aspect "sedang" can't be paired with conjunction like above, because in Mandarin that form of conjunction have semantics meaning: an event or activity that still happening.

Mandarin :

(X) jiejie yibian zuo zhe yibian chang zhe.

Indonesian :

$(\sqrt{ })$ kakak sedang memasak sambil menyanyi. Older sister is cooking while singing.

e. The usage of aspect "zhe" and adverb that indicate direction. The usage of aspect "zhe" in Mandarin and aspect "sedang" in Indonesian with the usage of adverb which indicate direction is totally different. Indonesian aspects "sedang" can directly be paired with adverb that indicate direction, while in Mandarin can't be directly paired with adverb that indicate direction because in Mandarin, adverb that indicate direction have semantics meaning an event or activity that still happening. So, it can't be directly paired with adverb that indicate direction. It needs to add "shi...de" form so it can be paired with adverb that indicate direction. While In Indonesian there are no "shi...de" form. And also, in Indonesian aspect "sedang" it can be directly paired with adverb that indicate direction because in Indonesian adverb that indicate direction doesn't indicate something that is still happening. Eg : 
Mandarin :

(X) ta bao zhe guo lai.

$(\sqrt{ })$ ta shi bao zhe guo lai de.

Indonesian :

$(\sqrt{ })$ dia sedang berlari kemari. He is come here running.

\subsubsection{The differences between aspect "le" and "sudah"}

a. The usage of aspect "sudah" in Indonesian and adverb of frequency.

Aspect "le" in Mandarin can't be paired with adverb of frequency such as "selalu, sering, terus-menerus". Because these adverbs of frequency are more likely emphasize the time where an event or action happens. It can be happened in past, present, or even future. While aspect le in Mandarin indicating an event or action that happened in the past, or it just recently happened. So that, aspect le and adverb of frequency can't be paired together. It is different with aspect "sudah". In Indonesian aspect "sudah" can be paired with adverb of frequency, because in this case adverb of frequency can be mean an action or event that have been occurred many times, and those events happened in the past or recently happened. Eg:

Mandarin :

(X) ta changchang shang xue chidao le.

Indonesian :

$(\sqrt{ })$ Dia sudah sering terlambat datang ke sekolah. He is usually came late to school.

b. The usage of le in Mandarin with the word "ba".

Aspect "sudah" in Indonesian can't be paired with "ba" because in Indonesian there isn't exist "ba" sentences. While in Mandarin "ba", can be paired with aspect le. It is indicating an action that contains order which happened in a very short of time. Eg:

Mandarin :

$(\sqrt{ })$ ba beizi de guochi he le!

Indonesian :

(X) Silahkan mengambil jus yang di gelas itu untuk di minum! Please take the juice in that glass for you to drink!

c. The placing of aspect "le" in Mandarin and Indonesian aspect "sedang" with verbs to be functioned as predicate or object.

Aspect "le" in Mandarin can only be placed after the verb that functioned as predicate. While aspect "sudah" in Indonesian can be placed before the verbs that can be fuctiones as predicate or object. Eg:

Mandarin :

$(X)$ ta renwei le wo zhidao ta de mima. $(\sqrt{ })$ ta renwei wozhidao le ta de mima. Indonesian : 
$(\sqrt{ })$ Dia mengira saya sudah mengetahui kode rahasianya. He already thinks that I know the password.

$(\sqrt{ })$ Dia sudah mengira saya mengetahui kode rahasianya. He thinks that I already know the password.

d. The usage of aspect le and direct sentences.

In Indonesian, aspect "sudah" can't be paired with direct sentences, because direct sentences can indicate an action or event that still happening so it can't be paired with the aspect that indicating action or event that already done or already happened. Meanwhile aspect "le" in Mandarin can be paired with direct sentences to indicate an action or event was recently finished.Eg:

Mandarin :

( $)$ Ta han le yi sheng :" xiaotou...xiaotou....!"

Indonesian

(X) Dia sedang berteriak : "pencuri...pencuri..!" she screams: "thief....thief..."

\subsubsection{The differences between aspect "guo" and "pernah"}

a. The usage of aspect "pernah" in Indonesian language with adverb of frequency (selalu, sering).

Aspect guo in Mandarin can't be paired with adverb of frequency such as "sering" or "selalu" (chang-chang/yi zhi) because these adverbs of frequency can indicating event that happened in the past, present, or future. While aspect guo can only indicate something that already happened in the past. So it can't be paired with adverb of frequency. Meanwhile aspect pernah in Indonesian can be paired with adverb of frequency to indicate an event/action that happened many times in the past. With the presence of adverb of frequency it emphasize that the action happened many times already. Eg:

Mandarin :

(X) yiqian wo zongshi wan er guo youxi.

Indonesian

$(\sqrt{ })$ Sebelumnya saya pernah selalu bermain game. Before, I always playing game

b. Reduplicated verb can't be paired with aspect pernah in Mandarin.

Aspect "guo" in Mandarin can't be paired with reduplicated verb, because reduplicated verb in Mandarin indicate an action or event that still happening, meanwhile aspect in Mandarin indicating event that already happened in the past. That is the reason why aspect "guo" in Mandarin can't be paired with reduplicated verb. It's different with aspect "pernah" in Indonesian which can be paired with reduplicated verb, because when a verb reduplicated it won't affect the time element, it only affects the meaning of the verb itself. In Indonesian, when the verb is reduplicated than it more easily (enjoy) to do, and not serious. Eg :

Mandarin 
(X) wo kankan guo bowuguan de hua.

Indonesian

$(\sqrt{ })$ saya pernah melihat-lihat lukisan di museum. I have ever been seen the painting in the museum.

c. The use of "jianglai" can be paired with aspect "guo" in Mandarin.

Aspect "pernah" in Indonesian can't be paired with the word "jianglai" because "jianglai" meaning is contrary with "pernah". Aspect pernah in Indonesian indicating an event or action that happen in the past, while "jianglai" indicating something that only happened in the future. Therefore, they can't be paired together. It's different with aspect "guo" in Mandarin. Aspect "guo" in Mandarin can be paired with the word "jianglai" because "jianglai" in this case can explain that the event can be happened in the future, which means that there is a belief that the event sure will be happened later, and if it is happened later that it is included in the event that already happened. Eg :

Mandarin

$(\sqrt{ })$ ni jian guo ci ren yihou like gaosu wo. If you met with this person later, please tell me ASAP.

Indonesian

(X) Jika kamu bertemu orang ini, segera beritahu saya (tidak ada penggunaan kata pernah).

d. Aspect pernah can be paired with modals.

Aspect "guo" in Mandarin can't be paired with modals such as "ingin", "dapat", "bias" (can, may, would). Because those modals indicating something that is uncertain which we don't know it will be happened or not or it will be done or not. Meanwhile, aspect "guo" indicating an event that already happened. On the other hand, aspect "pernah" in Indonesian can be paired with modals because those event is certainly known, can be done and can be happening. Eg :

Mandarin :

(X) wo xiangxin ta bu hui likai guo wo.

Indonesian

( $\sqrt{ })$ Saya percaya dia tidak akan pernah meninggalkanku. I believe, that he will not leave me.

\section{Conclusion}

From the explanation above we can conclude that there is a lot of differences between aspect in Mandarin and Indonesian. Those differences is one factor that make Indonesian students having difficulties in learning the aspect of Mandarin. Because there is a lot of Mandarin grammar structures which if it is paired with aspect "zhe", there will be the change in the structure form itself, so Indonesian student finding it as difficulties when learning the second language. Beside influences of the grammar structure, mother language (Indonesian) also one of the factor that became obstacle in order to learning the 
second language. Another obstacle can also came from another factors such as: the short amount of learning duration, environment, or the study method.

\section{References}

Jian M.L. (1998). “着(・Zhe)”字补议. 中国语文 Mandarin Language and Literature. 05, 331336. Retrieved from http://www.cnki.com.cn/index.html

Jian, M.L. \& Zhen, M. (1999). The Theory of modern Chinese Function Words. Language Press, Beijing

Kridalaksana, H. (2008). Kamus Linguistik. Jakarta: Gramedia Pustaka Utama.

Yu Z. S. (1992). 论现代汉语的“体”范畴Discourse about Mandarin Modern “Type” Scope. Mandarin Academy of Social Sciences, 06, 183-201. 